\title{
Endothelin-1 Measurement
}

National Cancer Institute

\section{Source}

National Cancer Institute. Endothelin-1 Measurement. NCI Thesaurus. Code C82008.

The determination of the amount of endothelin-1 present in a sample. 